\title{
EDITORIAL
}

\section{WAR IN CITIES: THE SPECTRE OF TOTAL WAR}

\section{Vincent Bernard, Editor-in-Chief}

A scene of devastation, blanketed with grey dust, stretches into the distance in eerie silence. Walls riddled with bullets, buildings collapsing in on themselves, external walls blown away to reveal an intimate view of a bedroom or living room, streets blocked by piles of rubble.

These sickening images of destruction - filmed from above by drones and shared on social media - probably best symbolize the current resurgence in urban warfare. Other images come to mind: bombed-out hospitals, children being pulled from wreckage, snipers roaming the maze of tunnels and walkways that have been blasted through the walls of now-uninhabited houses.

Contrasting starkly with these often deserted urban scenes of destruction are the pictures of overpopulated camps and makeshift boats brimming over with men, women and children. City-dwellers are often forcibly evacuated or driven to flee by conflict or hardship, with no choice but to leave behind their work, their relationships and the safety of their homes.

But not everyone can or wants to flee. For those who remain, life often becomes extremely dangerous and precarious when the complex fabric of urban services disintegrates: power, water and food supplies are cut off, leading to isolation, cold, darkness, illness and anxiety about what tomorrow may bring. As schools, businesses and shops close, people's future prospects disappear. Bombs - through negligence, error or criminal intent - strike people and the infrastructure they need to survive.

Gaza, Sana'a, Ramadi and Aleppo have recently joined the long list of cities that have been devastated by warfare throughout history, and other cities in Syria and Iraq may soon go the same way. After an issue dealing with how war has changed, and with future editions due to cover displacement, migration and the conflict in Syria, the International Review of the Red Cross felt the need to address the subject of urban warfare, not just because of the humanitarian crises that are continuing to unfold, but because urbanization is an unstoppable trend. Tomorrow's wars will inevitably take place in urban areas, where more than half of the world's population now lives. According to the United Nations (UN) World Urbanization Prospects report, urban population growth is accelerating. Only $30 \%$ of the world's population lived in cities in 1950 , but the figure was $54 \%$ in 2014 and is projected to rise to $66 \%$ in $2050 .{ }^{1}$

1 UN Department of Economic and Social Affairs, Population Division, World Urbanization Prospects, the 2014 Revision: Highlights, 2014, available at: https://esa.un.org/unpd/wup/Publications/Files/WUP2014Highlights.pdf (all internet references were accessed in February 2017). 
In 2010, the Review dedicated an issue to instances of urban violence that do not reach the threshold of armed conflict. ${ }^{2}$ In this issue we have chosen to focus on urban conflicts which do reach that threshold, dealing with the operational and political issues, the rules governing the methods and means of warfare, and the challenges in providing a humanitarian response.

\section{War in cities: a microcosm of total war}

Until the twentieth century, the standard model of war on land involved two main types of military operation: a confrontation on a battlefield in open country, or a siege of a city or fortress. The cities of Europe and Asia were protected by fortifications that were manned by troops when attacked, requiring the attacker to mobilize a greater force and commit to an operation that often proved long and costly if the city had sufficient provisions.

A little like an insect that has a shell but no internal skeleton, a city's defences were concentrated around its perimeter. Streets and buildings very rarely turned into battlefields, except during popular uprisings such as the Paris revolutions with their barricades. Once the besieging force broke through the ramparts, the whole city fell into its hands. This happened to Rome and Constantinople on several occasions. Jerusalem was besieged forty times and completely destroyed on two occasions. ${ }^{3}$

Despite the perception that more civilians were spared in past wars than in modern wars, the fate of a city's population during these sieges was inextricably linked with that of its defenders. Up to the time of the Napoleonic wars, a victorious military commander would allow or even encourage his troops to pillage the city. ${ }^{4}$ The population was then subjected to all kinds of violence, and sometimes enslaved or completely massacred, as in the Bible's description of the fall of Jericho: "And they utterly destroyed all that was in the city, both man and woman, young and old, and ox, and sheep, and ass, with the edge of the sword." 5 In that vein, ancient and medieval siege warfare could be seen as the precursor to genocide and total war.

Urban warfare as we know it today was relatively rare until the twentieth century, only really coming to prominence during the Spanish Civil War and the Sino-Japanese War in the 1930s. From Barcelona to Fallujah, via Huế and Grozny, the tactics involved in street battles have hardly changed. ${ }^{6}$ A city's outer walls are no match for modern artillery and getting through them is no longer a problem, so it is the urban fabric itself that becomes the battleground. Buildings

2 International Review of the Red Cross, Vol. 92, No. 878, 2010.

3 Jean Lartéguy, Mourir pour Jérusalem, Éditions de Fallois, Paris, 1995, p. 5.

4 See Gavin Daly, "Plunder on the Peninsula: British Soldiers and Local Civilians during the Peninsular War, 1808-1813", in Erica Charters, Even Rosenhaft and Hannah Smith (eds), Civilians and War in Europe, 1618-1815, Liverpool University Press, Liverpool, 2012, pp. 211-212.

5 Joshua 6:21.

6 See Alexandre Vautravers, "Military Operations in Urban Areas", International Review of the Red Cross, Vol. 92, No. 878, 2010. 
become bunkers, sewers become communication routes, and fighting takes place at very short range in a three-dimensional space, between buildings, between floors and between rooms.

It was also in the 1930s that the first large-scale aerial bombardments took place. In Europe, the bombing of Guernica, a small town in Spain's Basque Country, caused international outrage. Yet, nearly all belligerents of World War II soon followed that example and engaged in bombing the cities of their enemies.

The indiscriminate bombing of cities was not only a violation of international humanitarian law $(\mathrm{IHL})^{7}$ but was ineffective as a way of overcoming an opponent's resistance. The Blitz - the Luftwaffe's bombing of London in the Second World War - failed to bring Britain to its knees. Similarly, Germany's industrial capacity grew constantly during that war, ${ }^{8}$ despite ever more intensive air raids. Bombing cities is even counterproductive in some cases: ${ }^{9}$ it can strengthen people's desire to take revenge and can divert military resources towards targets that are of no military interest. The terrible siege of Leningrad only contributed to rallying the Russians against the Nazi invasion. Worse, a ruined city gives a number of tactical advantages to its defenders, as the German army found to its cost in the so-called War of the Rats (Rattenkrieg) in Stalingrad. Nevertheless, in the Second World War, the belligerents used the concept of "total war" to justify bombing the enemy's urban, industrial and commercial centres. As a result of that strategy, and in breach of international law, people living in cities again became the direct target of attacks, as they had been during sieges in ancient times and the Middle Ages. The distinction between front line and rear, and between soldier and civilian, becomes blurred in these situations. This type of bombing killed a million civilians during the Second World War, for a military advantage that was uncertain at best. ${ }^{10}$

Since the 1930s, cities have seen all kinds of violence: the crushing of the Warsaw Ghetto Uprising as part of the Shoah, the bombing of Tokyo in the Second World War, the occupation of Gaza, and counter-insurgency efforts related to the war on terror in four battles in Fallujah since 2004 and now in Mosul. Berlin still shows evidence of bombing, street fighting and the division created by the wall, like a body bears the scars of its injuries. Kabul and Baghdad have been ravaged by war several times in the last few decades, and continue to suffer repeated attacks. Because cities are highly symbolic, they are also the preferred target of terror attacks, recent examples being New York, Mumbai, Paris and Nairobi.

7 See Hague Convention (IV), Articles 25-27. Article 25: "The attack or bombardment, by whatever means, of towns, villages, dwellings, or buildings which are undefended is prohibited." Article 26: "The officer in command of an attacking force must, before commencing a bombardment, except in cases of assault, do all in his power to warn the authorities." Article 27: "In sieges and bombardments all necessary steps must be taken to spare, as far as possible, buildings dedicated to religion, art, science, or charitable purposes, historic monuments, hospitals, and places where the sick and wounded are collected, provided they are not being used at the time for military purposes. It is the duty of the besieged to indicate the presence of such buildings or places by distinctive and visible signs, which shall be notified to the enemy beforehand."

8 Richard Overy, The Bombing War, Europe 1939-1945, Penguin Books, London, 2014, p. 609.

9 See the previous issue of the Review on "The Evolution of Warfare" (Vol. 97, No. 900, 2015), and particularly the interview with Richard Overy therein.

10 Ibid., interview with Richard Overy. 
In the last few months, several cities and districts have been besieged in Syria and Iraq in a way not seen since the war in the former Yugoslavia and the siege of Sarajevo (1993-96). By laying siege to a city, the attacker does not have to risk its troops in dangerous street fighting, and can let famine and exhaustion take their toll. According to the UN, almost a million people were living in besieged cities and districts in Syria at the end of 2016. ${ }^{11}$ According to the president of the International Committee of the Red Cross (ICRC), Peter Maurer, Aleppo is experiencing "one of the most devastating urban conflicts in modern times". ${ }^{12}$

According to Michael Evans, "[i]n the decades ahead, it is a melancholy possibility that some cities in the developing world may become contested battlespaces - zones of conflict that will require the integration of the military art with the physical morphology and social geography of modern urban planning". ${ }^{13}$ Several contemporary military thinkers, such as Evans in this issue of the Review, suggest we should brace ourselves for a fresh upsurge in military operations in urban areas. ${ }^{14} \mathrm{In}$ Out of the Mountains: The Coming Age of the Urban Guerrilla, ${ }^{15}$ David Kilcullen concludes that counter-insurgency theories have not sufficiently taken account of current developments like the growth in the global population, urbanization, the rapid spread of technology with military applications such as drones, and advances in communications. He postulates that the conflicts of the future are likely to take place increasingly within the urban jungle of cities; armed forces would do well to prepare for the growing trend for armed groups to fight in cities.

Current events seem to bear this out: cities are again becoming the focal point of battles, partly because of a series of factors specific to modern conflicts. The vast majority of these conflicts involve armed groups fighting each other or government forces. Armed groups are sometimes born in cities, or they may hide in cities to benefit from the terrain: drawing the enemy into terrain that gives you an offensive or defensive advantage is a basic tactical ploy, and fighting in a city allows armed groups to make up for their relative weakness in these "asymmetric warfare" situations. In a sense, the city levels the playing field. The technological superiority of governments equipped with modern military hardware means that armed groups have no chance of success if a battle takes place in open country, so they hide in the urban fabric, blending in with the city's population.

Some armed forces may try to avoid street fighting, which causes devastation and is very costly in terms of both military losses and media and

11 Stephen O'Brien, Under-Secretary General for Humanitarian Affairs and Emergency Relief Coordinator, Statement to the Security Council on Syria, New York, 21 November 2016, available at: https:/docs.unocha. org/sites/dms/Documents/ERC_USG_Stephen_OBrien_Statement_on_Syria_to_SecCo21NOV2016CAD.pdf

12 See: www.icrc.org/en/document/syria-news-cities-aleppo-one-most-devastating-urban-conflicts.

13 Michael Evans, City Without Joy: Urban Military Operations into the 21st Century, Australian Defence College, Occasional Paper No. 2, Canberra, 2007, p. 2, available at: www.defence.gov.au/ADC/ publications/Occasional/PublcnsOccasional_310310_CitywithoutJoy.pdf.

14 See Michael Evans, "Future war in cities: Urbanization's challenge to strategic studies in the 21st century" in this edition of the Review. See also Stephen Graham, Cities Under Siege: The New Military Urbanism, Verso, London, 2011.

15 David Kilcullen, Out of the Mountains: The Coming Age of the Urban Guerrilla, C. Hurst \& Co., London, 2013. 
political fallout. Others may use a disproportionate amount of force in repressing armed groups and the population that is perceived as supporting them.

\section{War in cities: The challenges}

Although urbanization is a broadly positive phenomenon, due to the development of industries, services and cultural activities that it allows, at the same time the modern city is both particularly exposed to violence and a vehicle for violence, because of its density, anonymity, interdependent infrastructure and dependence on resources. In the future, as cities become more connected and dependent on new technologies, new vulnerabilities will arise, leading to fears of future cyberattacks on public transports, the electricity grid or the banking system.

For people living in cities at war today, armed conflict has horrifying consequences. We have identified the following major challenges relating to the security of city-dwellers and the services they need to live and survive:

- Security: fighting, bombing, mines, improvised explosive devices (IEDs), unexploded ordnance and oppression by combatants mean that people's homes are no longer safe.

- Supplies of subsistence items: food and water are rationed, of poor quality or unavailable.

- Electricity and fuel supplies: these are limited, rationed or cut off.

- Health care: hospitals are damaged or destroyed, health-care staff become increasingly scarce, the quality of care falls, and there is a risk of epidemics spreading more easily.

- The future: people's ability to have an education, a job or any kind of future is compromised.

Where evacuation is possible, the sudden movement of thousands of people creates another major humanitarian challenge. For instance, it is estimated that 30,0000 people escaped Fallujah in a matter of three days, during the fierce fighting that took place in June 2016. ${ }^{16}$ The cities of concern are not just those that become battlefields, but also those that take in people forced to flee violence. Today, it is estimated that 65 million people have been displaced by violence, and $75 \%$ of them are living in cities. ${ }^{17}$

The issues arising from the destruction of cities are particularly great, not just for their populations but also for the whole international community. Rebuilding a city is enormously expensive: in 2016, the World Bank reported that

16 IRIN, “The Failure in Fallujah and How Lessons Must Be Learnt for Mosul”, 28 June 2016, available at: www.irinnews.org/analysis/2016/06/28/failure-fallujah. See also IRIN, “Iraq: Escaping Fallujah”, 29 June 2016, available at: www.icrc.org/en/document/iraq-cities-fallujah-displaced.

17 ICRC, Statement at the UN Conference on Housing and Sustainable Urban Development (Habitat III), Quito, Ecuador, 17-20 October 2016, available at: www.icrc.org/en/document/plenary-statement-icrchabitat-iii-united-nations-conference-housing-and-urban-development also in the Reports and documents section of this edition of the Review. 
rebuilding Yemen could cost $\$ 15$ billion, ${ }^{18}$ and rebuilding Syria more than $\$ 150$ billion. ${ }^{19}$ How much of this destruction could have been avoided if the fighters had complied more with IHL?

Aside from the physical destruction, there is other damage that cannot be repaired: the loss of human life, injuries, disease and the destruction of irreplaceable cultural heritage, both tangible and intangible. Not all of the consequences are immediately visible: urban conflict can also cause the division, dispersion or destruction of communities, psychological trauma, and a lack of education affecting one or more generations.

\section{Sparing the civilian population}

Recent conflicts have given rise to a series of serious violations of humanitarian law, particularly in cities: they include the use of chemical weapons, destruction of cultural property, sexual violence, indiscriminate shelling, deliberate targeting of civilian and medical infrastructure and terror attacks. Indiscriminate or direct attacks on civilians, captured fighters or fighters hors de combat are prohibited in all circumstances, in cities or anywhere else. In addition, given events in recent months, it is worth reiterating that the law forbids the use of starvation of the civilian population as a method of warfare, ${ }^{20}$ and that attacks against people, vehicles or buildings involved in medical and humanitarian activities are prohibited. ${ }^{21}$

But prohibited acts aside, fighting in a densely populated area poses a number of difficulties for the mere application of humanitarian law, and particularly of rules governing the methods and means of warfare. Even assuming that IHL is perfectly respected, the cumulative effect of attacks over the course of a prolonged conflict can lead to severe humanitarian consequences. Nowhere is the inherent tension in humanitarian law between military imperatives and demands of humanity more apparent than in a city. It is in cities that military objectives, the civilian population and infrastructure are most closely entwined.

18 Reported by Reuters, 17 August 2016, available at: www.reuters.com/article/us-yemen-security-damagesidUSKCN10R2B7.

19 Transcript of World Bank Group President Jim Yong Kim's opening press conference, 14 April 2016, available at: www.worldbank.org/en/news/speech/2016/04/14/transcript-world-bank-group-presidentjim-yong-kim-opening-press-conference.

20 Protocol Additional to the Geneva Conventions of 12 August 1949, and Relating to the Protection of Victims of International Armed Conflicts, 8 June 1977, 1125 UNTS 3 (entered into force 7 December 1978), Art. 54(1); Protocol Additional to the Geneva Conventions of 12 August 1949, and Relating to the Protection of Victims of Non-Internatioanl Armed Conflicts, 8 June 1977, 1125 UNTS 609 (entered into force 7 December 1978), Art. 14. See in particular Jean-Marie Henckaerts and Louise Doswald-Beck (eds), Customary International Humanitarian Law, Vol. 1: Rules, Cambridge University Press, Cambridge, 2005 (ICRC Customary Law Study), Rule 53; and for more information see JeanMarie Henckaerts, "Study on Customary International Humanitarian Law: A Contribution to the Understanding and Respect for the Rule of Law in Armed Conflict", International Review of the Red Cross, Vol. 87, No. 857, 2005.

21 See ICRC Customary Law Study, above note 20, Rules 28-32; and J.-M. Henckaerts, above note 20. 
One initial major concern is what happens to civilians within besieged cities or neighborhoods. To protect people from the effects of hostilities, humanitarian law provides for the evacuation of civilians. That remains a complex task in a city under siege, because it requires the agreement of both parties involved. One of the ICRC's main roles is to act as a neutral intermediary, and it has conducted these types of negotiations and operations many times. ${ }^{22}$ The civilian population also has the right to relief. In recent years, there has been much debate about the lawfulness of cross-border relief operations following failures experienced by international organizations trying to provide humanitarian relief in Syria. ${ }^{23}$ The Review has published a series of articles on the ability of humanitarian organizations to obtain safe passage and the State's consent to it. ${ }^{24}$

It could also be argued that greater compliance with humanitarian law in the conduct of hostilities on the ground, as well as measures designed to spare the city's infrastructure and civilian population as much as possible, would give people more chance of staying in their homes and would help to prevent the mass displacements we are seeing today. When entire populations are forced to flee violence, employing more customs officers at the borders of wealthy countries is not the answer. The solution lies in preventing or resolving conflicts. It also requires the parties to those conflicts to abide by humanitarian law.

The fate of displaced people and refugees is yet another argument for sparing the civilian population to become an international priority. Another major characteristic of recent conflicts is the involvement of external powers in support of one side. Abiding by IHL must be central to that relationship. Foreign allies must use their influence by making financial or military support conditional on local forces complying strictly with humanitarian law. This is the meaning of the obligation - set out in Article 1 common to the four universally ratified Geneva Conventions - "to respect and to ensure respect for" IHL. ${ }^{25}$

The use of explosive weapons in urban settings, particularly those that have a wide impact area, creates major challenges in terms of the basic principles of humanitarian law, namely the prohibition on indiscriminate and disproportionate attacks as well as the obligation to take precautions in attack. Although explosive weapons - like bombs, rockets and shells - are not prohibited as such under

22 See, for example, ICRC, "Aleppo: 'Evacuation could take days- thousands of people in need", 15 December 2016, available at: www.icrc.org/en/document/aleppo-evacuation-could-take-days-thousandspeople-need.

23 See, for example, Pierre Kraehenbuhl, “There Are No 'Good' or 'Bad' Civilians in Syria - We Must Help All Who Need Aid”, The Guardian, 3 March 2013, available at: www.theguardian.com/commentisfree/ 2013/mar/03/red-cross-aid-inside-syria.

24 See Rony Brauman, "Médecins Sans Frontières and the ICRC: Matters of Principle", International Review of the Red Cross, Vol. 94, No. 888, 2012; Emanuela-Chiara Gillard, "The Law Regulating Cross-Border Relief Operations", International Review of the Red Cross, Vol. 95, No. 890, 2013; Françoise BouchetSaulnier, "Consent to Humanitarian Access: An Obligation Triggered by Territorial Control, Not States' Rights", International Review of the Red Cross, Vol. 96, No. 893, 2014; "ICRC Q\&A and Lexicon on Humanitarian Access", International Review of the Red Cross, Vol. 96, No. 893, 2014.

25 See Knut Dörmann and Jose Serralvo, "Common Article 1 to the Geneva Conventions and the Obligation to Prevent International Humanitarian Law Violations", International Review of the Red Cross, Vol. 96, No. 895/896, 2014. 
humanitarian law, their use in urban settings creates a whole set of humanitarian problems. They kill and injure the city's inhabitants, destroy electricity infrastructure and disrupt networks of cables and pipes.

As well as their direct effects, explosive weapons can also give rise to a series of knock-on effects that accumulate and last for varying amounts of time, and are made worse by the complexity and interdependence of urban infrastructure - for example, the destruction of a transformer can shut down a whole hospital. The humanitarian consequences can be extremely serious, so the foreseeable knock-on effects must be taken into account when making a decision to attack and assessing whether the expected military advantage is proportional given the human cost.

In recent years, several organizations have started to assess the scale of this problem, and the Review has reflected this increasing awareness. ${ }^{26}$ The UN secretary-general has expressed his concern about the matter several times in the Protection of Civilians in Armed Conflict annual report. ${ }^{27}$ Working on the ground, the ICRC has witnessed first-hand the consequences of using explosive weapons in urban areas. It has carried out research ${ }^{28}$ and organized expert meetings ${ }^{29}$ to document their impact. Since 2009, it has made regular public statements on the matter.

The ICRC's position, adopted in similar terms by the whole International Red Cross and Red Crescent Movement, is clear: "due to the significant likelihood of indiscriminate effects and despite the absence of an express legal prohibition for specific types of weapons, the ICRC considers that explosive weapons with a wide impact area should be avoided in densely populated areas". ${ }^{30}$

This is a highly sensitive topic, because it potentially concerns all armed forces and the use of very common weapons. However, as the articles in this issue show, better compliance with humanitarian law is possible.

Firstly, technological advances in weapons, communications and intelligence gathering mean that the law can be applied more effectively. By making weapons more precise and focusing their blast effects, their impact is less indiscriminate. ${ }^{31}$ To assess the proportionality of an attack in an urban setting,

26 John Borrie and Maya Brehm, "Enhancing Civilian Protection from Use of Explosive Weapons in Populated Areas: Building a Policy and Research Agenda", International Review of the Red Cross, Vol. 93, No. 883, 2001.

27 See, for example, Report of the Secretary-General on the Protection of Civilians in Armed Conflict, UN Doc. S/2009/277, 29 May 2009, para. 36; Report of the Secretary-General on the Protection of Civilians in Armed Conflict, UN Doc. S/2010/579, 11 November 2011, para. 49; Report of the Secretary-General on the Protection of Civilians in Armed Conflict, UN Doc. S/2015/453, 18 June 2015, para. 30 ff.; Report of the Secretary-General on the Protection of Civilians in Armed Conflict, UN Doc. S/2016/ 447, 13 May 2016, para. $24 \mathrm{ff}$.

28 See, in particular, the report commissioned from Armament Research Services, available at: www.icrc.org/ en/document/explosive-weapons-populated-areas-use-effects. The ICRC has dedicated a page on its website to the subject, available at: www.icrc.org/en/explosive-weapons-populated-areas.

29 In February 2015, the ICRC organized an expert meeting on explosive weapons in populated areas, the report of which is available at: www.icrc.org/en/publication/4244-explosive-weapons-populated-areasexpert-meeting. The 16th Bruges Colloquium on IHL in 2015 was on the subject of urban warfare; see: www.icrc.org/en/document/bruges-colloquim-experts-discuss-urban-warfare.

30 See, in this issue, the ICRC's Q\&A on the use of explosive weapons in populated areas.

31 See, for example, Michael N. Schmitt, "Precision Attack and International Humanitarian Law", International Review of the Red Cross, Vol. 87, No. 859, 2005. 
and particularly its indirect impact, military commanders now have access to much better intelligence, for example through the use of drones. When making decisions, they should be assisted by their legal advisers, but also by engineers or architects who can understand and predict the possible implications for the urban services that are vital to civilians.

Secondly, policy changes regarding stabilization and counter-insurgency operations are also intended to minimize civilian losses. ${ }^{32}$ The expected military advantage of an attack can no longer be assessed separately from the political objective. Armed forces that fully understand their political and strategic interests may even go beyond the requirements of humanitarian law by adopting a stillhigher standard of protection. When an attacking force decides to take greater risks in order to avoid civilian losses, or when a defending force takes the necessary precautions to protect civilians in the areas it controls, this must be acknowledged and welcomed.

Finally - as the Review never tires of reminding its readers - preventative measures in peacetime, such as instructing troops in humanitarian law and adopting orders, procedures and punishments that ensure compliance with the law, are crucial. They are also achievable by all responsible parties.

\section{Total war, holistic response}

Today, it is estimated that almost 50 million people are affected by conflict in urban areas. ${ }^{33}$ This is a major challenge for humanitarian organizations. In Syria alone, between January and October 2016, the ICRC and the Syrian Arab Red Crescent provided drinking water to 15 million people and food to 8 million. Through their efforts, 1.1 million people were able to access health care. ${ }^{34}$ According to Peter Maurer, urban warfare has altered the humanitarian space: "It's not by chance when we look at the 15 largest conflicts in the world, in which ICRC is active, the emblematic names that come to mind are Aleppo, Homs, Luhansk, Donetsk, Maiduguri, Aden." ${ }^{35}$ Accordingly, the ICRC has recently dedicated pages on its website to cities in Iraq, ${ }^{36}$ Syria ${ }^{37}$ and South Sudan. ${ }^{38}$ It also shared its experience of urban conflict with the international community at the Habitat III conference in Quito in October 2016. ${ }^{39}$

32 See the article by Sahr Muhammed Ally in this issue of the Review.

33 ICRC, Urban Services during Protracted Armed Conflict: A Call for a Better Approach to Assisting Affected People, Geneva, 2015, available at: www.icrc.org/eng/assets/files/publications/icrc-002-4249.pdf.

34 See: www.icrc.org/en/where-we-work/middle-east/syria.

35 Clár Ní Chonghaile, "Urban Warfare Has Altered the Nature of Humanitarian Work, Says Red Cross Chief", The Guardian, 13 November 2015, available at: www.theguardian.com/global-development/ 2015/nov/13/urban-warfare-humanitarian-work-international-committee-red-cross-peter-maurer-citiesconflict.

36 See: www.icrc.org/en/where-we-work/middle-east/iraq/iraqi-cities-baghdad-ramadi-fallujah-mosul.

37 See: www.icrc.org/en/syrian-cities.

38 See: www.icrc.org/en/where-we-work/africa/south-sudan/south-sudan-cities-renk-yei-wau-juba.

39 See: https://habitat3.org. 
For humanitarian organizations, the first problem that arises involves gaining access to the people inside cities, to provide relief or help with evacuation. Humanitarian efforts are hampered by fighting and the fragmented nature of armed groups, as well as mines, IEDs and unexploded ordnance. As well as physical access issues, organizations also experience problems gaining acceptance for their humanitarian mission: they have to negotiate with the parties to the conflict, which often use water, food and electricity supplies as ways of putting pressure on their opponents.

The various urban services function together like the parts of a machine: they are highly interdependent, making them complex and also vulnerable, and the populace are more dependent on these services than their rural counterparts. Isolated measures are insufficient to repair or maintain urban services; they require a systemic response. Responding to urban crises is a difficult task, because an effective response requires a holistic approach encompassing a number of different methods and professional skills. That is why the first article in this issue of the Review is an interview with architect Eyal Weizman, founder of the Forensic Architecture research agency. His cutting-edge approach occupies a space where architecture, media and human rights intersect.

Whether the city is a theatre of war or a place of refuge, the lines between emergency intervention and development become blurred. In addition, many modern conflicts are protracted, and efforts to help residents must take into account the time factor. As we see over and over again in the news, residents and people involved in providing urban services who remain inside cities often show incredible tenacity, endurance and ability to withstand hardship, which humanitarians refer to as "resilience". ${ }^{40}$ Recognizing this, humanitarian organizations are increasingly seeking to improve people's ability to survive and adapt, rather than merely providing the temporary relief that is sufficient for a short-lived crisis. At the Habitat III conference, the ICRC called for the "new urban agenda" to keep "cities working for their people in the terrible conditions of conflict, disaster and violence". ${ }^{41}$

In conclusion, given the protracted urban conflicts taking place today and likely to take place in the future, a new approach is necessary to maintain essential infrastructure and services, health-care provision and support for people deprived of

40 Center for Civilians in Conflict, Waiting for No One: Civilian Survival Strategies in Syria, 7 April 2016, available at: http://civiliansinconflict.org/resources/pub/civilian-survival-strategies-in-syria; Patricia Justino, Resilience in Protracted Crises: Exploring Coping Mechanisms and Resilience of Households, Communities and Local Institutions, paper presented at the High-Level Expert Forum on Addressing Food Insecurity in Protracted Crises, Rome, 13-14 September 2012, available at: www.fao.org/ fileadmin/templates/cfs_high_level_forum/documents/Resilience_in_protracted_crises_PJustino_01.pdf; Patricia Justino, The Impact of Armed Civil Conflict on Household Welfare and Policy, IDS Working Papers, Vol. 2011, No. 384, 2011, available at: https://www.ids.ac.uk/files/dmfile/Wp384.pdf; Oliver Kaplan, "Nudging Armed Groups: How Civilians Transmit Norms of Protection", Stability: International Journal of Security and Development, Vol. 2, No. 3, 2013, available at: www. stabilityjournal.org/articles/10.5334/sta.cw/.

41 See the ICRC's statement at Habitat III, available at: www.icrc.org/en/document/plenary-statement-icrchabitat-iii-united-nations-conference-housing-and-urban-development, also in the "Reports and Documents" section of this issue of the Review. 
their liberty. This approach requires several changes. ${ }^{42}$ Humanitarian funding must evolve to allow organizations to keep fragile infrastructure up and running over the long term, rethinking the traditional distinction between development and emergency relief. Humanitarian and development organizations need help to enhance their technical expertise and operational capacity when responding to the complex requirements of urban systems. Finally, parties to a conflict must factor humanitarian law into their preparations for future wars in cities, and take into account the interconnected nature of a city's infrastructure when making tactical decisions.

Cities, where more people are living today than ever before, are likely to remain a focal point in conflicts. Indiscriminate bombing and siege warfare have resurfaced. The flight of residents from cities in Syria, Iraq and Afghanistan is creating an exodus of biblical proportions. With our experience, and given progress in the fields of law, technology and science, we have an urgent duty to act in order to ensure compliance with the law and prevent a return to the tragedies of the past. Urban war must not become total war.

NB: Since 2014, certain topics covered in the Review have formed the subject of research and debate cycles at the Humanitarium, the ICRC's conference centre in Geneva, and around the world. The various events organized and contributions made as part of these cycles inform each other and become part of a global conversation by being published on the ICRC website and on the Review's new Humanitarian Law and Policy blog, set up in 2016. Following on from cycles focusing on new technologies, the principles guiding humanitarian action and generating respect for the law, this issue of the Review will form the basis for a new cycle dealing with war in cities in 2017. That cycle will continue the debate between humanitarian organizations, academics, politicians and military leaders, in line with the Review's multidisciplinary approach, in order to achieve greater respect for the law. 